\title{
УРАХУВАННЯ СПЕЦИФІКИ ТОРГОВЕЛЬНИХ МЕРЕЖ У МОДЕЛЯХ ТРАНСПОРТНОЇ ЗАДАЧІ
}

\author{
Андрій Мазарчук, к.е.н., дочент; \\ Ганна Більовська, аспірант; \\ Украӥна, Хмельнищький, Хмельниц̧ький національний університет
}

DOI: https://doi.org/10.31435/rsglobal_ijite/30112018/6211

\begin{abstract}
ARTICLE INFO
Received 08 September 2018 Accepted 14 November 2018 Published 30 November 2018

\section{KEYWORDS}

transportation problem, dynamic simulation, multiproduct model, prioritization analysis, $\mathrm{ABC}$ analysis, profitability ratio. ABSTRACT

The article presents the results of the study of specific features of retail networks and ways of taking into account these features in the formation of a comprehensive model of management of product transportation in the network. The proposed comprehensive model takes into account such features of the retail network as multiproduct situation, indistinguishability of suppliers and consumers, availability of transit points, cost of storage at the transit point, capacity of warehouses and their load, transportation time and shelf life, priority of outlets and types of products, restrictions on capacity of transport. The proposed model allows solving multiproduct transport problems for trading networks of varying complexity, enabling decision makers to change the complexity of the model.
\end{abstract}

Citation: Андрій Мазарчук, Ганна Більовська. (2018) Urakhuvannia Spetsyfiky Torhovelnykh Merezh u Modeliakh Transportnoi Zadachi. International Journal of Innovative Technologies in Economy. 8(20). doi: 10.31435/rsglobal_ijite/30112018/6211

Copyright: (C) 2018 Андрій Мазарчук, Ганна Більовська. This is an open-access article distributed under the terms of the Creative Commons Attribution License (CC BY). The use, distribution or reproduction in other forums is permitted, provided the original author(s) or licensor are credited and that the original publication in this journal is cited, in accordance with accepted academic practice. No use, distribution or reproduction is permitted which does not comply with these terms.

Вступ. У процесі управління логістикою торговельних мереж особливе місце посідає прийняття транспортних рішень, а саме забезпечення своєчасного постачання якісної продукції до торгівельних точок мережі з мінімальними загальносистемними витратами. У економічній теорії такі рішення пропонується приймати 3 використанням моделей транспортних задач. Однак у класичному вигляді транспортна задача значно спрощує реальну проблему транспортування продукції до торговельних підприємств, тому на практиці використання транспортних моделей виявляється недоцільним, а управлінські рішення приймаються на основі евристичних рішень управлінського персоналу.

Проблемі адаптації моделей транспортної задачі для вирішення реальних задач управління логістикою присвячено праці Овчарук I.В., І Іваницької О. В., Рощиної Н.В., Сербул Р.С., Семерикова А.В., Жолткевич Г.М., Алі Найф Халіл Альх Жуж, Ярмоленко Л.І., Чумак Т.М., однак комплексної моделі для управління поставками для торговельних мереж все ще не було розроблено. Саме тому дослідження проблеми транспортування продукції 3 урахуванням специфіки торговельних мереж як цілісного організму залишається актуальним.

Метою статті $є$ створення та обгрунтування комплексної моделі транспортної задачі для торговельних мереж на основі класичної іiі постановки та аналізу напрацювань наукової спільноти у напрямку їі адаптації до реальних проблем управління логістикою.

Результати дослідження. Класична транспортна задача полягає у вирішенні проблеми забезпечення $\mathrm{n}$ споживачів необхідними $\mathrm{b}_{\mathrm{n}}$ обсягами однорідної продукції з використанням $\mathrm{m}$ постачальників, у кожного з яких наявні певні $\mathrm{a}_{\mathrm{m}}$ обсяги цієї продукції, при відомих тарифах на перевезення між пунктами $\mathrm{c}_{\mathrm{mn}}$. При цьому слід скласти оптимальний план перевезень, який мінімізує загальну вартість перевезень (або час перевезень) і задовольняє потреби споживачів, повністю використавши запаси постачальників [1]. 
Позначивши $\mathrm{x}_{\mathrm{ij}}$ - обсяг продукції, який планується перевезти з $\mathrm{i}$-го пункту постачання у j-ий пункт споживання, отримаємо математичну модель класичної транспортної задачі наступного вигляду $[1,2]$ :

$$
F=\sum_{i=1}^{m} \sum_{j=1}^{n} c_{i j} x_{i j} \rightarrow \min
$$

при виконанні умов:

$$
\begin{aligned}
& \sum_{\mathrm{j}=1}^{\mathrm{n}} \mathrm{x}_{\mathrm{ij}}=\mathrm{a}_{\mathrm{i}}(\mathrm{i}=\overline{1, \mathrm{~m}}), \\
& \sum_{\mathrm{m}=1}^{\mathrm{m}} \mathrm{x}_{\mathrm{ij}}=\mathrm{b}_{\mathrm{j}}(\mathrm{j}=\overline{1, \mathrm{n}}), \\
& x_{i j} \geq 0, i=\overline{1, m}, j=\overline{1, n} .
\end{aligned}
$$

Виконання умови (2) у даній моделі забезпечує вивезення товару 3 усіх пунктів постачання, а умови (3) - повне задоволення попиту на усіх пунктах споживання. Умова (4) передбачає отримання невід'ємних обсягів постачання [2].

Описана модель дозволяє отримати оптимальний план перевезень, однак у такій постановці значно спрощує реальну проблему, яку доводиться вирішувати торговельним мережам. Таке надмірне спрощення часто робить використання транспортної задачі непридатним для вирішення реальних завдань торговельних мереж, що спонукає їх до вибору часто ненадійних і залежних від досвіду осіб, що приймають рішення, евристичних методик. Однак цілком можливо допрацювати базову модель транспортної задачі таким чином, щоб адаптувати іiі для використання торговельними мережами у реальних ситуаціях.

Першим i найбільш очевидним ускладненням, яке слід ввести у базову модель транспортної задачі $є$ багатопродуктовість. Торговельні мережі у реальному житті пропонують споживачам широкий асортимент продукції, яка не $\epsilon$ однорідною чи взаємозамінною. Перетворення класичної моделі транспортної задачі у багатопродуктову здійснюється шляхом введення додаткового параметру $k=\overline{1, \ldots, r}$, де $r$ - кількість видів продукції, яку планується транспортувати, а також відповідно внесення змін до цільової функції моделі та їі обмежень.

Такі багатопродуктові транспортні задачі автор [3] пропонує вирішувати шляхом розбиття їх на одно продуктові підзадачі, кожна з яких вирішується окремо, а результати зводити у загальну таблицю. Однак такий підхід не дозволяє отримати адекватний оптимальний план перевезень внаслідок неврахування можливостей спільних перевезень різних видів продукції, обмежень обсягів наявних транспортних засобів та їх місткостей. Окрім цього, слід враховувати також і нерівноцінність різних видів продукції, перевезення якої планується у мережі. Деякі види продукції зазвичай $є$ більш пріоритетними, порівняно з іншими, приносять більший прибуток і втрати внаслідок їх дефіциту є більш значними. Тому забезпечувати попит на такі продукти слід в першу чергу.

Більш складним, однак ефективнішим підходом до вирішення багатопродуктових транспортних задач $є$ запропонований авторами [4] метод континуального лінійного програмування. Даний метод базується на проведенні певних математичних перетворень для зведення багатопродуктової вихідної задачі до двоїстої задачі континуального лінійного програмування та застосування до неї градієнтного алгоритму. При цьому автори розглядають динамічну модель транспортної задачі із додатковим обмеженням пропускної здатності дуги перевезень $(\mathrm{i}, \mathrm{j})$ у момент часу $\mathrm{t}$ - величина $\mathrm{u}_{\mathrm{ij}}(\mathrm{t})$.

У класичній моделі транспортної задачі чітко визначено перелік постачальників і споживачів, а продукція переміщується від перших до других. Для торговельних мереж слід враховувати той факт, що для забезпечення максимальної гнучкості продукція може надходити не лише від постачальників до торгових точок, а й від постачальників до складів, між складами, від складів до торгових точок і навіть між торговими точками. Таким чином, як склади, так i 
торгові точки при цьому виступають у транспортній задачі як споживачами, так i постачальниками одночасно.

Подібні задачі також було розглянуто автором [3] як задачі 3 нерозрізненими постачальниками і споживачами, для вирішення яких пропонується введення поняття буфера кількості всієї продукції, яка транспортується між учасниками. Дані буфери визначається як сума обсягів попиту кожного споживача та сума обсягів пропозиції кожного виробника, які додаються до відповідних обмежень. Таким чином, обмеження на обсяги попиту і пропозиції матимуть наступний вигляд:

$$
\begin{aligned}
& \sum_{\mathrm{j}=1}^{\mathrm{n}} \mathrm{x}_{\mathrm{ij}}{ }^{k}=\mathrm{a}_{\mathrm{i}}{ }^{k}+\sum_{\mathrm{i}=1}^{m} \mathrm{a}_{\mathrm{i}}{ }^{k}(\mathrm{i}=\overline{1, \mathrm{~m}} ; k=\overline{1, r}), \\
& \sum_{\mathrm{i}=1}^{\mathrm{m}} \mathrm{x}_{\mathrm{ij}}{ }^{k}=\mathrm{b}_{\mathrm{j}}{ }^{k}+\sum_{i=1}^{n} \mathrm{~b}_{\mathrm{j}}{ }^{k}(\mathrm{j}=\overline{1, \mathrm{n} ;}, k=\overline{1, r}) .
\end{aligned}
$$

Автор [3] наголошує, що завдяки введенню понять транзитних пунктів та буфера, з'являється можливість вирішення багатьох транспортних задач різної складності.

Також важливою умовою класичної моделі транспортної задачі $€$ задані значення тарифів перевезень між пунктами. Однак у реальних ситуаціях на формування фактичної загальної вартості перевезень чинять вплив не лише тарифи перевезення, а й безліч інших показників. Зокрема, надзвичайно важливим є час транспортування продукції між пунктами, вартість зберігання продукції на складах як проміжних, так і на складах торгових точок. При цьому обов'язково слід враховувати місткість складів, наявність достатнього місця для зберігання необхідного обсягу продукції з урахуванням наповнення складів у даний момент іншими видами продукції, наявність необхідних умов для зберігання відповідної продукції (особливо актуально для продуктових торговельних мереж).

Вартість зберігання продукції на складах у різних точках торговельної мережі в моделі транспортної задачі можна врахувати, встановивши дані показники у якості так званих тарифів перевезення вантажу всередині відповідного вузла транспортної мережі. При відсутності належних умов зберігання певного виду продукції на певному складі мережі, тариф перевезення відповідного виду продукції в даному вузлі мережі встановлюється значно вищим, ніж усі інші тарифи мережі. Місткість складів та їх завантаження можна врахувати, застосовуючи уже згадане обмеження пропускної здатності дуги перевезень в одиницю часу.

Час транспортування продукції та його обмеження можуть бути враховані при застосуванні динамічної моделі транспортної задачі. Таким чином, цільова функція моделі матиме вигляд [4]:

$$
\int_{t_{0}}^{t_{1}} \sum_{k=1}^{r} \sum_{i=1}^{m} \sum_{j=1}^{n} c_{i j}{ }^{k}(t) x_{i j}{ }^{k}(t) d t \rightarrow \min .
$$

Обмеження на час транспортування продукції тоді матиме наступний вигляд:

$$
\sum_{i=1}^{m} \sum_{j=1}^{n} t_{i j}^{k} \leq t^{k}
$$

Для продуктових торговельних мереж важливим показником також є термін зберігання продукції, оскільки при досить тривалому транспортуванні таких товарів до кінцевих точок продажу скорочується можливий період їх продажу, підвищується ймовірність понесення збитків внаслідок закінчення строку придатності таких товарів, що у свою чергу впливає на загальносистемні витрати. Для таких товарів в обмеженні (8) під $t^{k}$ матиметься на увазі строк зберігання k-ої продукції збільшений на обсяг орієнтовного часу для реалізації даного виду продукції у точці продажу. 
Слід також враховувати той факт, що вартість продажу одного і того ж товару, як i обсяг попиту на нього, може різнитися у різних точках продажу торговельної мережі, залежно від їх місця розташування. Відповідно у різних точках продажу мережі будуть різнитися втрати внаслідок дефіциту продукту. Також у кожній точці продажу будуть різнитися втрати внаслідок дефіциту різних товарів. Таким чином, у транспортній моделі слід враховувати пріоритетність груп товарів та точок продажу. При чому пріоритетність товарів можна визначати як у кожній торговельній точці мережі, так і в усій мережі в цілому.

Пріоритетність товарів та точок мережі можна визначити, використавши комбінацію ABC та XYZ-аналізу, запропоновану у дослідженнях Ярмоленко Л.І. та Чумак Т.В. [5]. АВСаналіз дозволяє ранжувати товари або торгові точки відповідно до їх внеску у загальний прибуток (TR) торговельної мережі або окремої торговельної точки.

Критерієм ранжування при застосуванні XYZ-аналізу є мінливість попиту на товар або ж мінливість показника загального прибутку. Характеристикою такої мінливості у XYZ-аналізі $\epsilon$ коефіцієнт варіації.

Поєднавши результати ранжування об’єктів з допомогою АВС та XYZ-аналізу за один і той же проміжок часу, отримаємо емпірично обгрунтовані групи товарів або торгових точок за ступенем значимості у загальному результаті торговельної мережі, а отже визначимо, на користь яких товарів і торгових точок слід вирішувати транспортну задачу в першу чергу. У разі високої складності отриманої моделі транспортної задачі можна розбити іiі на підзадачі відповідно до отриманих в результаті ранжування груп товарів чи торгових точок. Також отримані подібним чином результати ранжування торгових точок дозволять визначити об'єкти мережі, попит яких у товарі слід задовольняти в першу чергу, не допускаючи там дефіциту.

Таким чином, застосування комбінації АBC та XYZ-аналізу надає можливість особам, які приймають управлінські рішення, евристично визначати ступінь деталізації постановки транспортної задачі відповідно до потреб управління.

Пріоритетність продукції та точок продажу в транспортній мережі також можна враховувати, використовуючи коефіцієнт прибутковості товару чи точки продажу. Такий коефіцієнт показує, в якій мірі прибутковість відповідного товару у відповідній точці продажу перевищує середній рівень прибутковості усіх товарів по мережі (формула 9).

$$
k T R_{i}^{k}=\frac{T R_{i}^{k} \times \sum_{i=1}^{n} k_{i}}{\sum T R}-1,
$$

де $T R_{i}^{k}$ - обсяг прибутку від реалізації товару k у точці продажу $\mathrm{i} ; \sum T R$ - загальний обсяг прибутку від реалізації всіх товарів у мережі; $\sum_{i=1}^{n} k_{i}-$ загальна кількість видів товарів, взятих до уваги у точках продажу мережі (тобто, кількість точок спостереження або обсяг вибірки).

Отримані коефіцієнти прибутковості в моделі можна врахувати, відкоригувавши 3 їх допомогою тарифи на перевезення продукції наступним чином:

$$
c_{i j}^{k s}=\left(1-L \times k T R_{j}^{k}\right) \times c_{i j}^{k}
$$

де $c_{i j}^{k}$ - вихідне значення тарифу перевезення k-го товару від точки і до точки j; $k T R_{j}^{k}-$ коефіцієнт прибутковості к-го товару у кінцевій точці дуги ij; $L \in[0 ; 1]$ - ступінь урахування коефіцієнтів прибутковості при розрахунку тарифів перевезення.

3 допомогою коригування тарифів перевезення наведеним чином, можна враховувати у транспортній задачі той факт, що перспектива отримання вищого прибутку від продажу більш прибуткових товарів у більш прибуткових точках продажу може компенсувати можливу вищу вартість доставки таких товарів у ці точки, порівняно із менш пріоритетними напрямками поставок. У той же час можливий дефіцит у пріоритетних точках продажу буде викликати вищий рівень збитків у разі невчасного постачання товарів у ці точки. Задаючи значення змінної $L$, особа, що приймає управлінські рішення, може самостійно визначати, у якій мірі враховувати коефіцієнти прибутковості товарів у моделі транспортної задачі. 
Після отримання оптимального плану перевезень задачі із коригованими коефіцієнтами залишиться лише обчислити загальні витрати на перевезення товарів у мережі відповідно до вихідних (фактичних) тарифів перевезень.

Варто зазначити, що зазвичай торговельні мережі для перевезень продукції між об'єктами мережі використовують власний парк транспортних засобів, або ж користуються послугами компаній-перевізників. У кожному 3 цих випадків у розпорядженні мережі $\epsilon$ обмежений обсяг транспортних засобів із обмеженою місткістю і вантажопідйомністю. Даний фактор також значною мірою впливає на прийняття логістичних рішень, тому повинен обов'язково враховуватись у моделі. Такі обмеження на транспорт можуть враховуватись у моделі через уже наявне обмеження пропускної здатності дуги мережі в момент часу t.

Врахувавши усі описані особливості торговельних мереж, модель транспортної задачі для торговельної мережі матиме наступний вигляд:

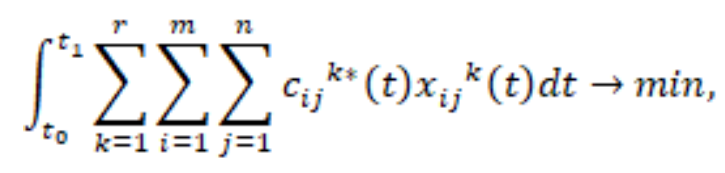

за умови, що:

$$
\begin{gathered}
\int_{t_{0}}^{t_{1}} \sum_{i=1}^{m} x_{i j}^{k}(t) d t \geq b_{j}^{k}+\sum_{j=1}^{n} b_{j}^{k}(k=\overline{1, r}), \\
\int_{t_{0}}^{t_{1}} \sum_{j=1}^{n} x_{i j}^{k}(t) d t \leq a_{i}^{k}+\sum_{i=1}^{m} a_{i}^{k}(k=\overline{1, r}), \\
\sum_{k=1}^{r} x_{i j}^{k}(t) \leq u_{i j}(t) \quad(i=\overline{1, m} ; j=\overline{1, n}), \\
\sum_{i=1}^{m} \sum_{j=1}^{n} t_{i j}^{k} \leq t^{k}(k=\overline{1, r}), \\
x_{i j}^{k} \geq 0, i=\overline{1, m}, j=\overline{1, n}, k=\overline{1, r}, \\
\sum_{i=1}^{m} a_{i}^{k}=\sum_{j=1}^{n} b_{j}^{k}(k=\overline{1, r}) .
\end{gathered}
$$

Відповідно до критерію (11) отриманої моделі, слід організувати перевезення $\mathrm{r}$ видів продукції через торговельну мережу на протязі часу $\left[t_{0} ; t_{1}\right] 3$ мінімальними загальними витратами, враховуючи пріоритетність продукції та точок продажу. Тарифи перевезення $c_{i j}{ }^{k *}$ моделі обчислюються відповідно до формули (10).

Нерівність (12) ілюструє умову забезпечення сумарного попиту споживачів ј за період часу $\left[t_{0} ; t_{1}\right]$ із допуском можливості використання пунктів продажу у якості транзитних пунктів мережі, а нерівність (13) - сумарні можливості постачальників і за той же період часу. Умова (14) задає обмеження на об'єми перевезень вантажів по дугах мережі із врахуванням їх пропускної здатності, формула (15) -обмеження на час транспортування продукції по дугах мережі. Система нерівностей (16) виражає природню вимогу невід'ємності багатопродуктового потоку у торговельній мережі, а система (17) - виконання умови балансу, тобто рівності сумарної інтегральної пропозиції сумарному інтегральному попиту для кожного продукту.

Висновки. Запропонована модель дозволяє вирішувати багатопродуктові транспортні задачі для торговельних мереж різної складності, надаючи можливість особам, що приймають управлінські рішення, змінювати складність моделі, а також міру врахування пріоритетності торгових точок і продукції. При цьому враховуються специфічні особливості проблеми транспортування продукції в торговельній мережі: багатопродуктовість, нерозрізненість 
постачальників і споживачів, наявність транзитних пунктів, вартість зберігання продукції у транзитному пункті, місткість складів та їх завантаженість, час транспортування та термін зберігання продукції, пріоритетність торгових точок та видів продукції, обмеження на місткість транспорту.

\section{ЛІТЕРАТУРА}

1. Овчарук I.В. Розв’язання транспортної задачі, як складова підготовки бакалаврів з економіки та підприємництва / І. В. Овчарук, В. О. Овчарук // Водний транспорт. - 2013. - Вип. 2. - С. 195-202.

2. Іваницька О. В. Транспортна задача лінійного програмування / О. В. Іваницька, Н. В. Рощина, Р. С. Сербул // Агросвіт. - 2015. - № 14. - С. 35 - 40.

3. Семериков А.В. Решение транспортных задач: Учебное пособие/ А.В. Семериков - Ухта:УГТУ, 2013. $-58 \mathrm{c}$.

4. Жолткевич Г.М. Багатопродуктова транспортна задача континуального лінійного програмування/ Г.М. Жолткевич, Алі Найф Халіл АльхЖуж// Системи обробки інформації. - 2006. - Вип. 3(52). - с. 49-53.

5. Ярмоленко Л.І. Удосконалення системи управління запасами дистриб'юторської фірми/ Л.І. Ярмоленко, Т.В. Чумак// Академічний огляд. - 2017. - № 1(46). - c.83-91. 